\title{
Ethno Medicinal, Phyto Chemical and Therapeutic Importance of Physalis angulata L.: A Review
}

\author{
Dr. P. Ayodhyareddy*, P. Rupa** \\ *Assistant Professor in Zoology, Government Degree and P.G College (A), Siddipet, Medak (D), Telangana, India, 502103 \\ ***ecturer in Botany (P.G), Government Degree and P.G College (A), Siddipet, Medak (D), Telangana, India, 502103
}

Corresponding Author Email ID: rupareddyputta[at]gmail.com

\begin{abstract}
Physalis angulata L. belonging to nightshade plant family Solanaceae. It shows cosmopolitan habitat and easily available in both Andhra Pradesh and Telangna, India. The plant has shown great ethno medicinal importance and high medicinal values. The present review paper expressed the profile of Physalis angulata $L$. as well as its ethno medicine, phytochemistry and therapeutic importance. Most of the research, in vitro and in vivo studies of this plant throughout the world has proven its antimicrobial, antibacterial, anticancer, antimalaria, antitumor, antileukemia, antihyperglycemic, antitrypanosomal, antiallergic, antiprotozoan, antioxidant, antinociceptive, antiasthmatic, anti-inflammatory, antimolluscan, antituberculosis immunomodulatory and antiviral, activities.
\end{abstract}

Keywords: Physalis angulata L, Phytochemistry, Ethno medicine, Therapeutic activities, Anticancer, Antimalaria and Antimicrobial

\section{Introduction}

Physalis angulata $\mathrm{L}$. belonging to nightshade plant family Solanaceae (Sudhakar Reddy et al., 2009) accredited with medicinal properties and contains different classes of secondary metabolites of pharmacological importance. In Andhra Pradesh and Telangana Physalis angulata L. commonly called as budda kodisha and budda gochi respectively (Sudhakar reddy et al., 2014).

\section{Common Names}

Annual ground cherry, Bladder berry, Bush tomato, Chinese lantern, Cut leaf ground cherry, Goose berry, Ground cherry, Angular winter cherry, Balloon cherry, Husk tomato, Indian gooseberry weed, Mullaca, Native gooseberry, Wild gooseberry, Wild tomato, Hogweed, Winter cherry, Battre-autour, Bolsa mullaca, Camapu and Cape gooseberry.

Origin:

This species probably originated in tropical America, but is now widespread throughout tropical and sub-tropical regions of the world (i.e. almost cosmopolitan)

\section{Distribution and Habitat}

$P$. angulata is a plant of urban open spaces, disturbed areas, roadsides, croplands, orchards, nurseries and fallow land. It grows best in moist, fertile soils, prefers full sun conditions but it is also tolerant of partial shade. In general, across its wide distribution, $P$. angulata is considered a plant of tropical, sub-tropical and warm temperate conditions. It can occasionally be a hydrophyte but also occurs in uplands (USDA-NRCS, 2013). Whistler (1988) indicated the habitat of $P$. angulata to be croplands and disturbed places. It infests primarily annual crops but also occurs in orchards, nurseries, fallow land, roadsides and waste areas.Physalis angulata L. occurring in India as an adventives weed, occupying the nutrient- rich (garbage) soils. Its identity, as a distinct species, is now wellestablished (Reddy et al., 1999). Physalis angulata L. propagates easily by the seed germination. Spontaneous clumps of plants can be found along river banks and just about anywhere the soil is disturbed and the canopy is broken (allowing enough sunlight to promote its rapid growth).

\section{Taxonomy:}

Kingdom: Plantae

Subkingdom: Tracheobionta

Division: Magnoliophyta

Class: Magnoliopsida

Subclass: Asteridae

Order: Solanales

Family: Solanaceae

Genus: Physalis

Species: angulata $\mathrm{L}$.

\section{Morphology of Physalis angulata L.}

Physalis angulata L. (Solanaceae) is an annual herb indigenous to many parts of the tropics, including the Amazon. It can be found on most continents in the tropics, including Africa, Asia, and the Americas. The plant grows up to $1 \mathrm{~m}$ high, plants are erect and robust, plant parts are more or less smooth and glabrescent, bears small, yellowcolored flowers, and produces small, light yellowishorange, edible fruit sometimes referred to as cape gooseberry or cut leaf ground cherry. The leaves are less oblique, more dentate, ovate to lanceolate, $4-10 \mathrm{~cm}$ long and $3-6 \mathrm{~cm}$ wide. The petioles are up to $4 \mathrm{~cm}$ long or longer. The leaf margin is usually irregularly toothed but may be smooth. The leaf bases are unequal. The flowers are borne on stalks from $5-40 \mathrm{~mm}$ in length. The corolla is yellow, usually without spots or occasionally with distinct spots, and is from $4-12 \mathrm{~mm}$ long and $6-12 \mathrm{~mm}$ wide. The anthers are bluish or violet, up to $2.5 \mathrm{~mm}$ long and are 


\section{International Journal of Science and Research (IJSR) \\ ISSN (Online): 2319-7064}

Index Copernicus Value (2013): 6.14 | Impact Factor (2015): 6.391

borne on stalks up to $5 \mathrm{~mm}$ long. The green outer layer is 4-7 $\mathrm{mm}$ long with triangular lobes about as long as the tube. The fruit is about the size of a cherry tomato, and like tomatoes, it contains many tiny edible seeds inside. It is usually hairless; however, occasional plants have short apprised hairs especially on the younger parts. The fruit is enclosed in the outer layer.This outer layer (calyx) grows around and encloses the fruit, becomes 10-angled or ribbed, $20-35 \mathrm{~mm}$ long and from $15-25 \mathrm{~mm}$ wide; it is borne on a stalk 1-4 cm long. The fruit is succulent in nature and tangy in taste although sometimes it may be bitter (Reddy KN et al., 2007), (Sachidananda and Prasad, 1996).

\section{Cytology of Physalis angulata L.}

Most sources suggest a basic chromosome number of $\mathrm{n}=$ 12, although (Raju et al. 2007) refer to it being a tetraploid species $(2 n=48)$.

\section{Ethano medicinal importance of Physalis angulata $\mathbf{L}$.}

Physalis angulata $\mathrm{L}$.is an annual herb indigenous to many parts of the tropical areas of Africa, Asia and America including the Amazon (Bastos, et al., 2006). Physalis angulata $\mathrm{L}$. has long held a place in natural medicine in the tropical countries where it grows. In India, some people of Madhya Pradesh, Utter Pradesh and Uttharkand used the plant for the treatment of asthama (Chhaya Rathore, et al., 2011). This herb has been used in traditional medicine as analgesic, anti rheumatic, to treat sore throat and abdominal pain. It is also considered as antipyretic, antinociceptive, antidiuretic, and antiinflammatory drug for hepatitis and cervicitis (Lin et al., 1992, Bastos et al., 2008). Number of lines evidenced that this plant is traditionally used for the treatment of malaria, asthma, and fever (dos Santos et al., 2003, Soares et al., 2003). In Amazon valley, Physalis angulata L. is popularly known as "camapu" and its juice is used as sedative, depurative, anti-rheumatic, and for the relief of earache (Bastos et al., 2008). Physalis angulata L. is also used as a traditional medicine preparation for diabetes, hepatitis, asthma and malaria in Taiwan (Hsieh et al., 2006). In Western Africa Physalis angulata L. (Koropo) used as a traditional medicine for the treatment of cancer (Lawal et al., 2010). Herbal practitioners in both South and North America today rely on mullaca for various bacterial and viral infections as well as a complementary therapy for cancer and leukemia (Taylor and Leslie, 2003).Externally the entire plant has been used in traditional herbal medicine systems for skin sores, rashes, pruritis and earaches (Branch, 1983, Coee et al., 1996 and Jovel et al., 1996). The many-seeded fruit is edible when ripe (Hall et al., 1991). Its berries are often used as food by Aborigines in several regions of Australia (South Australia, 2012). In tropical Africa the fruit is eaten as a snack, but eating too much of the fruit may cause dizziness. The leaves are eaten in salads, although they taste bitter.

\section{Phyto Chemical Constituents of Physalis angulata L.:}

Phytochemical studies on physalis angulata L. reveal that many types of biologically active, naturally occurring chemicals including flavonoids, alkaloids and plant steroids known as physalins, B, D, F and G, withanolides and secosteroids which have never been seen in science before are present. Chemicals include Ayanin, choline, chlorogenicacid, ixocarpanolide, myricetin, phygrine, physagulin A thru $G$, physalin A thru $K$, physangulide, sitosterol, vamonolide, withaminimin, withangulatin $\mathrm{A}$, withanolide D, withanolide $\mathrm{T}$, withaphysanolide (Ramachandra Row et al., 1980, Chen et al., 1990, BASEY et al., 1992 and Shingu et al., 1992). Physalis angulata L. has been the subject of recent clinical research, based on the preliminary studies showing that it is an effective immune stimulant, toxic to numerous types of cancer like leukemia and shown antimicrobial properties. Plant steroids of Physalis angulata L. are called Physalins, have shown strong in vitro and in vivo (mice) activity against numerous types of human and animal cancer cells including lung, colon, nasopharynx, liver, cervix, melanoma and glioma (brain) cancer cells. This cancer research began in the early 1980s with researchers in Thailand and the U.S. and was verified with research performance at the University of Taiwan in 1992 (where they demonstrated a significant effect against five human cancer cell lines and three animal cancer cell lines). Then in 2001, researchers at the University of Houston isolated yet another new chemical in Physalis angulata L. which demonstrated remarkable toxicity against nasopharynx cancer cells, lung (adenocarcinoma) cancer cells as well as leukemia in mice. The same Taiwanese researchers had already published a separate study on mullaca's other antileukemic phytochemicals in 1992, reporting that two Physalin chemicals inhibited the growth of five types of acute leukemia, including lymphoid ( $\mathrm{T} \& \mathrm{~B}$ ), promyelocytic, myeloid and monocytic.

\section{Biological activities and Clinical research}

\section{Antimicrobial, Anti protozoan and Anti bacterial activity:}

Methanol extracts of the entire plant at $2 \mathrm{mg} / \mathrm{ml}$ showed in vitro activity against Klebsiella sp., Corynebacterium diphtheriae, Neisseria sp., Pseudomonas aeruginosa, Staphylococcus aureus, and Streptococcus sp (Ogunlana and Ramstad, 1975). An ethanol-water leaf extract at 50 ul/agar plate was inactive against Neisseria gonorrhea (Caceres et al., 1995). In vitro study, complex physalin metabolites present in the capsules of the fruit of Physalis angulata $\mathrm{L}$. have been isolated and submitted to a series of assays of antimicrobial activity against Pseudomonas aeruginosa, Staphylococcus aureus, Neisseria gonorrhoeae, Escherichia coli and Candida albicans. Physalin B (200 microg/ml) by the agar diffusion assay inhibited S. aureus (Silva et al., 2005).

\section{Anti mycobacterial activity:}

Ethanol, chloroform, hydroalcoholic and chemical fractions of the leaf and aerial parts of Physalis angulata L.demonstrated anti mycobacterial activity in vitro at 32$625 \mathrm{mcg} / \mathrm{ml}$. Activity was against the following Mycobacterium:M. tuberculosis, $M$. intracellulare, $M$. malmoense, M. avium and M. kansasi (Januario et al., 


\section{International Journal of Science and Research (IJSR) \\ ISSN (Online): 2319-7064}

Index Copernicus Value (2013): 6.14 | Impact Factor (2015): 6.391

2002). A leaf ethanol extract showed the maximum activity at $32 \mathrm{mcg} / \mathrm{ml}$ towards $M$. tuberculosis (Pietro et al., 2000). Chloroform extracts were active towards a maximum number of organisms at a lower dose than the hydroalcoholic extracts (Januario et al., 2002).Crude extracts and fractions from aerial parts of Physalis angulata L.have been bioassayed for anti mycobacterial activity. Fractions containing Physalins B, F and D exhibited a minimum inhibitory concentration value (MIC) against M. tuberculosis (Januário et al., 2002).

\section{Anti viral activity:}

A hot water extract of the aerial parts of the plant at 0.1 $\mathrm{mg} / \mathrm{ml}$ showed in vitro activity against Poliovirus (Kurokawa et al., 1993). At $340 \mathrm{mcg} / \mathrm{ml}$ a methanol extract showed protease inhibition in vitro; a water extract was inactive.

\section{Anti malarial:}

A plant decoction using mullaca (Physalis angulata L.) along with Jatropha curcas, Gossypium hirsutum and Delonix regia, was administered to malaria patients. The complex eliminated malaria parasites (Plasmodium falciparum and Plasmodium malarie) from the peripheral blood of malaria patients. No undesired effects were seen. In rats the herbal complex affected select cytochrome p450 isozymes in relation to the sex of the rat, indicating it may precipitate interactions with other drugs via liver transformation and elimination (Ankrah et al., 2003).

\section{Anti trypanosomal activity:}

Various extracts of the aerial parts, leaf, root and fruit showed in vitro anti trypanosomal activity against Trypanosoma brucei rhodesiense between the concentrations of $19-56 \mathrm{mcg} / \mathrm{ml}$ (Freiburghaus et al., 1996).

\section{Antioxidant activity:}

In DPPH radical scavenging assay of Physalis angulata L. exhibited free radical scavenging ability or antioxidant activity in a concentration dependant manner. The antioxidant property of plant extracts could be useful in the treatment of free radical pathologies (Ayodhya reddy etal., 2012).

\section{Molluscicidal activity:}

Ethyl acetate and acetone extracts from the whole plant and ethanol extracts of the roots between $0.1-500 \mathrm{mg} / \mathrm{L}$ had in vitro molluscicidal activity against Biomphalaria tenagophila. Aqueous slurry of the fruit, roots and leaves was inactive against Lymnaea columella and Lymnaea cubensis in vitro (Medina and Woodbury, 1979).

\section{Vector control activity:}

In evaluation of In-vitro vector control activity of Physalis angulata L., the crude ethanolic extract significantly demonstrated paralysis and also caused death of the helminthes especially at higher concentration of $50 \mathrm{mg} / \mathrm{ml}$, as compared to standard reference piperazine citrate. Similarly very optimistic results were observed for Culex quniquefasicatus species of mosquito larvae (Sandhya et al., 2010).

\section{Cytotoxic and Antitumor activity:}

A methanol leaf extract in cats was active against human lung carcinoma cells. In invitro studies, ethanol extracts of the entire plant at $10 \mathrm{mcg} / \mathrm{ml}$ were active against the following cell lines: human oral epidermoid carcinoma (Ca-9KB); human colon cancer; human lung cancer (lu-1); human cervical adenocarcinoma (HeLa), hepatoma-2 and hepatoma-HA22T (Chiang et al., 1992).

\section{Antileukemia activity:}

Researchers of China and Russia independently demonstrated the significant immuno modulatory effects against blastogenesis (a process triggered in leukemia) while boosting other immune functions which might account for the anti-leukemic effects in mice.

\section{Anticancer activity:}

In tumor cells, the steroidal chemicals of Physalis angulata L. were suppress an enzyme level to arrest the normal cell cycle in cancer cell, cause DNA damage inside of cancer cells and making them unable to replicate. Physalins B and F were isolated from the ethanolic extract of the whole plant of Physalis angulata L. inhibited the growth of several human leukemia cells: K562 (erythro leukemia), APM1840 (acute T lymphoid leukemia), HL60 (acute promyelocytic leukemia), KG-1 (acute myeloid leukemia), CTV1 (acute monocytic leukemia) and B cell (acute B lymphoid leukemia) (Chiang HC et al., 1992). Physalin B can induce apoptosis of melanoma cancer cells via the NOXA, caspase-3, and mitochondria-mediated pathways, but not of human skin fibroblast cells and myoblastic cells (Chia-Chun Hsua et al., 2012).

\section{Anti-hepatoma activity:}

The aqueous and ethanol extracts of Physalisangulata and $P$. peruviana whole plants EEPP possesses potent antihepatoma activity and its effect on apoptosis is associated with mitochondrial dysfunction (Shu-Jing Wua et al., 2004).

\section{Immunomodulatory activity:}

In vitro ethanol extracts of the entire plant at $0.39-20 \mathrm{mcg}$ stimulated T-lymphocyte blastogenesis. At $10 \mathrm{mcg}$ antibody formation was enhanced in mice (Lin et al. 1992).

\section{Antinociceptive activity:}

Aqueous extract of roots of Physalis angulata L. on mice shown antinociceptive activity (Bastosa et al., 2006). 


\section{International Journal of Science and Research (IJSR) \\ ISSN (Online): 2319-7064}

Index Copernicus Value (2013): 6.14 | Impact Factor (2015): 6.391

Anti-inflammatory activity:

Flower extracts at $200 \mathrm{mg} / \mathrm{kg}$ orally in mice inhibited acute and subacute carrageenan-induced paw edema, arachidonic acid-induced ear edema and formaldehyde-induced arthritis (Choi and Hwang, 2003).Aqueous extracts exert powerful anti-inflammatory and immunomodulatory activities, interfering with the cyclo oxygenase pathway, lymphocyte proliferation, NO, and TGF- $\beta$ production (Pinto et al., 2010).

\section{Anti-allergic activity:}

Flower extracts at $200 \mathrm{mg} / \mathrm{kg}$ orally, administered for 1 week, inhibited 2, 4-dinitro fluoro benzene- induced contact hypersensitivity type IV allergic reaction in mice (Choi and Hwang, 2003).

\section{Anti hyperglycemic activity}

A water extract of the root given intra gastrically to mice had weak hypoglycemic activity (Richter and Carlson, 1998).

\section{Anti asthmatic activity:}

The methanolic extract of leaves exhibited antagonistic activity on both histaminergic and serotonergic receptors (Chhaya et al., 2011).

\section{Conclusion}

Physalis angulata L. anti cancerous and anti leukemic actions, several research groups have confirmed antibacterial and antiviral activity. Physalis angulata L. was shown to be active in vitro against several strains of Mycobacteria and Mycoplasmas (both very stubborn types of bacteria which are not widely susceptible to standard antibiotics). In addition to these actions, Physalis angulata L. has demonstrated effective anti bacterial properties in vitro against numerous types of gram positive and gram negative bacteria, including Pseudomonas, Staphylococcus and Streptococcus. Other research groups in Japan have been focusing on Physalis angulata L. antiviral activities and preliminary studies show that it is active in vitro against Polio viruse-I, Herpes simplex viruse-I, the Measles viruse and HIV-I - demonstrating reverse transcriptase inhibitory effects. Physalis angulata L. has also been reported to reduce sparms in guinea pigs, lower blood pressure in cats and to contract isotonic muscles in toads. In the test tube, Physalis angulata L. was shown to have an anticoagulant effect. Western scientists did somewhat validate the indigenous use for diabetes when they reported a mild hypoglycemic effect in mice fed a water extract of the root.
Figures and Tables:

Figure 1 \& 2: Physalis angulata L. plant with flowers and fruits

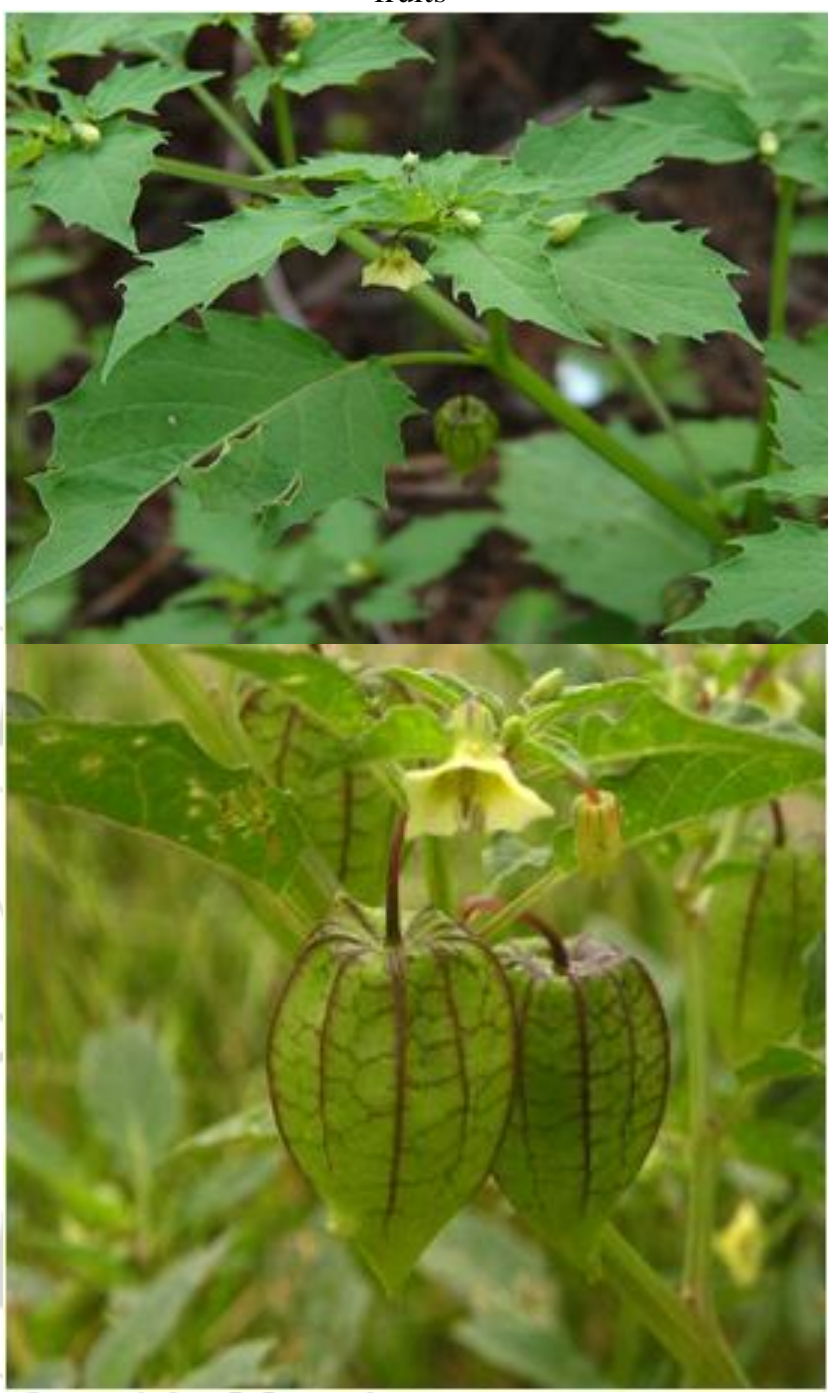

Table 1: Morphological characters of Physalis angulata L.

\begin{tabular}{|l|l|}
\hline Plant parts & more or less smooth or glabrescent \\
\hline Leaves & less oblique, more dentate \\
\hline Flower (corolla) & $>7 \mathrm{~mm}$ across, pale yellow or white \\
\hline Anthers & Bluish \\
\hline Fruiting pedicels & $>1 \mathrm{~cm}$ \\
\hline Fruiting calyces & $\begin{array}{l}\text { tingled purple, 5-ribbed(weakly 10-angled), } \\
\text { ovoid }\end{array}$ \\
\hline
\end{tabular}

Table 2: Ethanomedicinal importance of Physalis angulata $\mathrm{L}$

(Source: Technical Data Report of Sage Press. 2002.)

\begin{tabular}{|l|l|}
\hline $\begin{array}{l}\text { Plant } \\
\text { parts }\end{array}$ & Medicinal Importance \\
\hline $\begin{array}{l}\text { Entire } \\
\text { Plant }\end{array}$ & $\begin{array}{l}\text { Childbirth, diuretic, fever, liver diseases, gonorrhea, } \\
\text { jaundice, malaria, } \\
\text { nephritis, postpartum hemorrhage, rashes, skin sores, } \\
\text { sleeping sickness, } \\
\text { to prevent abortion and tumors. }\end{array}$ \\
\hline Fruit & $\begin{array}{l}\text { Infection, infertility, inflammation, postpartum } \\
\text { infection, pruritis and skin diseases. }\end{array}$ \\
\hline Leaf & $\begin{array}{l}\text { Asthma, dermatosis, diarrhea, diuretic, earache, fever, } \\
\text { gonorrhea, hemorrhage, } \\
\text { hepatitis, infections, inflammation, liver disorders, } \\
\text { malaria, postpartum infection, }\end{array}$ \\
\hline
\end{tabular}




\begin{tabular}{|l|l|}
\hline & $\begin{array}{l}\text { pruritis, rheumatism, skin diseases, prevent abortion } \\
\text { and worms. }\end{array}$ \\
\hline Sap & Earache, postpartum infection and pruritis. \\
\hline Root & $\begin{array}{l}\text { Diabetes, earache, fever, hepatitis, jaundice, liver } \\
\text { disorders, malaria, rheumatism. }\end{array}$ \\
\hline Stem & Hepatitis. \\
\hline Seed & Infertility
\end{tabular}

\section{References}

[1] Ankrah NA, Nyarko AK, Addo PG, Ofosuhene M, Dzokoto C, Marley E, Addae MM, Ekuban FA(2003): Evaluation of efficacy and safety of a herbal medicine used for the treatment of malaria. Phytother. Res.; 17(6): 697-701.

[2] Ayodhyareddy.P,

Krishnareddy.M, Narsimhareddy.Y(2012): Anti diabetic activity of medicinal plant extracts in streptozotocin induced albino rats (Thesis).

[3] Basey K, Mcgaw BA, Woolley JG. (1992): Phygrine an alkaloid from Physalis species. PhytoChemistry; 31 (12): 4173-4176.

[4] Bastos CNT, Silveira AJA, Salgado CG, PicancoDiniz DLW, de Nascimento JLM, (2008) Physalis angulata extracts exerts anti-inflammatory effects in rats inhibiting different pathways. Journal of Etnhopharmacology; 118, 251-264.

[5] Branch LC and Da Silva IMF (1983: Folk Medicine of Alter do Chao, Para, Brazil. Acta Amazonica.; 13(6):737-797.

[6] Caceres A, Menendez H, Mendez E, Cohobon E, Samayoa BE, Jauregui E, Peralta E, Carrillo G, 1995): Anti gonorrhoeal activity of plants used in Guatemala for the treatment of Sexually Transmitted Diseases.J. Ethnopharmacol.; 48(2): 85-88.

[7] Chia-Chun Hsua, Yang-Chang Wua, Lynn Farhd, Ying-Chi Dua, Wei-Kung Tsenge, Chau-Chung Wuf, Fang-Rong Changa. (2012): Physalin B from Physalis angulata triggers the NOXA-related apoptosis pathway of human melanoma A375 cells. Food and Chemical Toxicology; 50(4):619-624.

[8] Choi EM, Hwang JK. (2003): Investigations of antiinflammatory and antinociceptive activities of Piper cubeba, Physalis angulata and Rosa hybrid. J. Ethnopharmacol.; 89(1): 171-175.

[9] Freiburghaus F, Kaminsky R, Nkunya MH, Brun R, (1996): Evaluation of African medicinal plants for their in vitro trypanocidal activity. J. Ethnopharmacol.; 55(1): 1-11.

[10] Chen CM, Chen Z, Hsich C, Zin W, Wen S. (1990):Withangulatin A new Withanolide from Physalis angulata L. Heterocycles; 31(7): 371-375.

[11]Chhaya Rathore KR, Dutt Shobharam Sahu and Lokesh Deb, (2011): Antiasthmatic activity of the methanolic extract of Physalis angulata Linn.: Journal of Medicinal Plants Research; 5(22):351-355.

[12] Chiang HC, Jaw SM, Chen PM. (1992): Inhibitory effects of physalin B and physalin $\mathrm{F}$ on various human leukemia cells in vitro. Anticancer Res.; 12(4):155162.

[13] Coee FG, Anderson GJ, Econ BOT, (1996): Screening of medicinal plants used by the Garifuna of Eastern
Nicaragua for bioactive compounds.

$\mathrm{J}$. Ethnopharmacol. ; 53: 29-50.

[14] Dos Santos JA, Tomassini TC, Xavier DC, Riberio IM, da Silva MT, de Morais Filho JB. (2003): Molluscicidal activity of Physalis angulata L.extracts and fractions on Biomphalaria tenagophila under laboratory conditions. Memorias do Instituto Oswaldo Cruz.; 98: 425-428.

[15] Hall DW, Vandiver VV, Sellers BA, 1991. Cutleaf Ground-cherry, Physalis angulata L. Cutleaf Groundcherry, Physalis angulata L. Florida, USA: University of Florida.

[16] Hsieh WT, Huang KY, Lin HY, Chung JG. (2006): Physalis angulata induced G2/M phase arrest in human breast cancer cells. Food and Chemical Toxicology, 44: 974-983.

[17] Januário AH, Filhom ER, Pietro RC, Kashima S, Sato DN, França SC. (2002): Antimycobacterial physalins from Physalis angulata L. (Solanaceae). Phytother. Res. 16(5): 445-448.

[18] Jovel EM, Cabanillas J GHN Towers, (1996): An ethnobotanical study of the traditional medicine of the Mestizo people of Suni Mirano, Loreto, Peru. J. Ethnopharmacol.; 53: 149-156.

[19] Kurokawa M, Ochiai H, Nagasaka K, Neki M, Xu H, Kadota S, Sutardjo S, Matsumoto T, Namba T, Shiraki K, (1993): Antiviral traditional medicines against Herpes simplex virus (HSV-1), Poliovirus, and Measles virus in vitro and their therapeutic efficacies for HSV-1 infection in mice. Antiviral Res.; 22(3): 175-188.

[20] Lawal IO, Uzokwe NE, Igboanugo ABI, Adio AF, Awuson EA, Nwogwugwu JO, Faloye B, Olatunji BP, Adesoga AA(2010): Ethnomedicinal information on collection and identification of some medicinal plants in research institutes of South-west Nigeria. African Journal of Pharmacy and Pharmacology; 4: 1-7.

[21] Lin YS, Chiang HC, Kan WS, Hone E, Shih SJ, Won MH, (1992):Immunomodulatory activity of various fractions derived from Physalis angulata L. extract. Amer. J. Chinese Med. 1992; 20(4): 233-24.

[22] Medina FR and Woodbury R.(1979): Terrestrial plants molluscicidal to lymnaeid hosts of Fasciliasis hepatica in Puerto Rico.J.Agr. Univ. Puerto Rico: 63: 366376.

[23] Ogunlana EO and Ramstad E (1975): Investigations into the antibacterial activities of local plants. Planta Med.; 27: 354-60.

[24] Pietro RC, Kashima S, Sato DN, Januário AH, França SC. (2000): In vitro anti mycobacterial activities of Physalis angulata L. Phytomedicine; 7(4): 335-338.

[25] Pinto NB, Morais TC, Carvalho KMB, Silva CR, Andrade GM, Brito GAC, Veras ML, Pessoa ODL, Rao VS, Santos FA. (2010) ; Phytomedicine. 17(10):740-743

[26] Raju VS, Reddy CS, Rajarao KG, 2007. The myth of "minima" and "maxima", the species of Physalis in the Indian subcontinent. Journal of Systematics and Evolution, 45(2):239-245.

[27] Ramachandra Row L, Sambi Reddy K, Subrahmanya Sarma N, Teruo Matsuura and Ruka Nakashima(1980): New physalins from Physalis angulata and Physalis lancifolia. Structure and 


\section{International Journal of Science and Research (IJSR) \\ ISSN (Online): 2319-7064}

Index Copernicus Value (2013): 6.14 | Impact Factor (2015): 6.391

reactions of physalins $\mathrm{D}, \mathrm{I}, \mathrm{G}$ and $\mathrm{K}$. PhytoChemistry.; 19: 1175-1181.

[28] Reddy KN, Patnayak Reddy CS, Raju VS. Traditional Knowledge on wild food plants in Andhra Pradesh. Indian Journal of Traditional Knowledge. 2007; 6 (1): 223-226.

[29] Richter RK, Carlson TJ.(1998): Reporting biological assay results on tropical medicinal plants to host country collaborators. J. Ethnopharmacol.; 62(1): 8588.

[30] Sachidananda and Prasad (1996): Encyclopedic profile of Indian Tribes: vol 3: Botanical Survey of India, Calcutta.

[31] Sandhya S, Jafferi SAH, Vinod KR, Ottilia Banji, David Banji, Chaitanya RSN, Chandrasekhar J, Venkataramana K. (2010): Evaluation of In-vitro vector control activity of Physalis angulata. Hygeia.J.D.Med:2 (2):14-21.

[32] Shu-Jing Wua, Lean-Teik Ngc, Ching-Hsein Chend, Doung-Liang Line, Shyh-Shyan Wange, Chun-Ching Lin (2004): Antihepatoma activity of Physalis angulata and $P$. peruviana extracts and their effects on apoptosis in human Hep G2 cells. Life Sciences: March; 74(16):2061-2073.

[33] Silva MT, Simas SM, Batista TG, Cardarelli P, Tomassini TC. (2006): Studies on antimicrobial activity, in vitro, of Physalis angulata L. (Solanaceae) fraction and physalin B bringing out the importance of assay determination. Mem Inst Oswaldo Cruz. Epub 100 (7):779-82.

[34] Singh KN and Bhardwaj VR.(1975): Hypo- glycaemic activity of Albizzia moluccana and Caesia fistula leguminous seed diets on normal young rats. Indian $\mathbf{J}$ Pharma- col. 7(1):47-51.

[35] Shingu K, Yahara $S$, Okabe $H$, Nohara $T$. (1992):Three new withanolides, physagulins E, F and G from Physalis angulata L. Chem. Pharm. Bull.; 40. 2448-245.

[36] South Australia, (2012): Physalis angulata: Electronic Flora of South Australia (online), Australia.http://www.flora.sa.gov.au/efsa/lucid/Solana ceae/Solanaceae\%20species/key/Australian\%20Solan aceae\%20species/Media/Html/Physalis_angulata.htm.

[37] Sudhakar Reddy C, Reddy KN, Murthy EN and Raju VS. Traditional medicinal plants in Seshachalam hills, Andhra Pradesh. India Journal of Medicinal Plants Research. 2009; 3(5): 408-412.

[38] Sudhakar Reddy C, K.R.L.Sarany, P.Hari Krishna, S.Vazeed Pasha, K.V.Satish and C.S.Jha(2014):Flora of NRSC Shadhnagar Campus.

[39] Technical Data Report of Sage Press. 2002

[40] USDA-NRCS, (2013): Plants profile for Physalis angulata (cutleaf groundcherry). http://plants.usda.gov/core/profile?symbol=phan5.

[41] Whistler WA, 1988. Checklist of the weed flora of Western Polynesia. An annotated list of the weed species of Samoa, Tonga, Niue, and Wallis and Futuna, along with the earliest dates of collection and the local names. Technical Paper, South Pacific Commission, No. 194:69 pp. 